\title{
The Regional Integration Agreements: A New Face of Protectionism
}

\author{
Montej Abida ${ }^{1}$ \\ ${ }^{1}$ School of Business, University of Sfax, Tunisia \\ Correspondence: Montej Abida, School of Business, BP 1081 Sfax 3018, Tunisia. Tel: 216-98-487-913. E-mail: \\ montejabida@gmail.com
}

Received: December 19, 2012

Accepted: January 14, $2013 \quad$ Online Published: February 22, 2013

doi:10.5539/ijef.v5n3p183

URL: http://dx.doi.org/10.5539/ijef.v5n3p183

\begin{abstract}
The regional integration agreements can be a strategy of trade diversion and thus we can say that there is a violation of the rules of free trade. By creating preferential rules which are inconsistent with the principles of the WTO, the strategy of regional integration can increase the risk of trade disputes with third party countries and can therefore generate a commercial environment full of threats and reprisals. Third countries, especially developing countries have small markets, may find themselves marginalized further when the members of the regional group adopt the principle of discrimination.

The philosophy of the WTO paves the way for a transition from regional integration towards a multilateral integration. The question that arises is whether regional integration agreements meet this conception of the WTO or they represent a new form of protectionism hindering free trade. We know that the regional groups hold private information about the actions and decisions they adopt in the intra-group. The uncertainty and hidden information can cause conflicts internationally.

The WTO, we can assume as the Principal, should create incentives that can guide regional groups that can be assumed as Peripheral Agents, to comply with Article XXIV and the elimination of regional protectionism. Control actions and trade policies of regional groups should be done on a regular basis to make the game of international trade more fair.
\end{abstract}

Keywords: regional integration, protectionism, free trade, trade policy, W.T.O, Principal-Agent model

\section{Introduction}

An increasingly common strategy tends to want substituting a regionalization of the world economy for multilateralism. Indeed, after the end of the Cold War, the countries were divided into regional entities. It is obvious that despite the economic crisis and the inability of a single national strategy, the policies of regional integration become desirable. This is, especially, due to the success of European integration that has encouraged the countries to regroup. Many countries launch new regional integration projects or revive old ones.

The strategy of regional integration helped to divide the world into three major economic regions, each of them is centered around a pole: Europe around the European Union, America around the United States, Asia around Japan. Each of these three major economic powers is trying to attract as many countries as possible by signing the preferential agreements. It is mainly the developing countries cling to these three areas in order to find the breath required to start their own economies.

Even if the regional integration does not fit into the philosophy of multilateralism, the WTO is the exception to the principle of non-discrimination and authorizes the establishment of a regional group. Indeed, the WTO was believed that if one starts with regional trade cooperation, we will eventually trade cooperation at the international level. But in reality, the most of the agreements of the regional integration are not interpreted and applied as necessary as the rules set forth in Article XXIV of the WTO. The question is whether the regional integration may undermine multilateralism or not. In other words, we must know what the implications of the strategy of regional integration are in the multilateral trading system.

The most of countries have understood that it is better to come together to achieve the economic development (Shadikhodjaev 2009). Going it alone is not profitable. Therefore, the regional integration strategy encourages the member countries to cooperation and economic development. It is creating customs unions and free trade 
areas. This strategy aims to remove the barriers for the competition and to allow a more efficient allocation of resources to increase the production and to improve the well-being of each country.

It was after the Second World War, and more exactly after the creation of the European Economic Community (EEC) in 1957, the strategy of regional integration has been reappeared. Indeed, the regional integration agreements which are signed in 1547-1548 between England and Scotland show that these agreements are not new. In general, it is from the 16th century several regional integration agreements have been signed in order to eliminate or reduce, on a mutual basis, all the barriers to the free movement of goods.

It is very appropriate to report back a wave of the regional integration agreements, as well as deepening and widening of existing of the agreements in recent decades. Indeed, in 31 July 2010, 474 RTAs had been notified to the GATT / WTO, the notifications for goods and those for services have been recognized separately. Concerning these RTAs, 351 were notified under the Article XXIV of the GATT 1947 or GATT 1994; 31 under the Enabling Clause and 92 under the Article V of the GATS. On the same date, 283 agreements were entered by force.

\section{Regionalism and Multilateralism: A Review of the Literature}

It is legitimate to ask if the strategy of regional integration will have an influence on the multilateral trading system. The new international political and economic order created by the end of the Cold War seems to be involved in the abandonment of the enlargement strategy and regional integration. The question is why countries are moving towards regional integration strategy while there is a multilateral trading system. Is that because the regional integration agreements are more effective than multilateral trade agreements in progress towards free trade? It is also important to know if the regional integration agreements help or hinder multilateralism (Siroën 2000a, Trotignon 2009).

Several theoretical and empirical studies (Hauser and Zimmermann 2001, Khavand 2001, Crawford and Laird 2001, OECD 2003, Mashayekhi and Taisuke 2005, Baldwin 2009), examined the interplay between the multilateral trading system and Preferential Trade Agreements (PTAs ). Most of these studies have asked whether PTAs promote or hinder multilateral tariff reductions (Hauser and Zimmermann 2001, Khavand 2001, Baldwin and Jaimovich 2007 and 2009). The objective is to analyze the effect of preferential tariff reductions on the Law of the Most Favoured Nation (MFN).

The examples studied in this work focus on the case of free trade agreements North American "NAFTA" (Baldwin 2009, Goyette 2006, Deblock and Dorval 1993, Tshiyembe 2012) and the case of the European Union (Baldwin 2010, Kearney 2008, Clergerie, Gruber and Ramband 2010, European Commission 2008). In recent decades, the case of the formation of a regional group in Asia has attracted several researchers (Figuière and Guilhot 2009, 2007). Indeed, Baldwin (2010) suggests that we must learn from the example of regional integration in Europe. It assumes that the spontaneous cooperation that created the factory in Asia has not been codified. He suggested to institutionalize the spontaneous cooperation that already exists on trade, services and investment.

By using the domino theory, Baldwin and Venables (1995) presented a model of enlargement of the European Union. Indeed, this theory shows that the potential loss of market share encourages non-members to adhere to existing PTAs, which generates a process of action and reaction or infection. The model of the domino effect was used again by Baldwin and Jaimovich (2009) in order to see whether the bilateral agreements are contagious or not. These two authors have shown that exporters of non-member countries push their politicians to join the PTAs existing or create new ones to avoid damage that could result in preferential trade liberalization.

Baldwin (2009) examined the systemic effects, that is to say, the static and dynamic effects, PTAs on multilateralism. Static effects are, for example, the existence of conflicting rules, including on trade remedies. Dynamic effects are, among others, the impact of PTAs on the probability that countries undertake new multilateral negotiations.

From their sides, Baldwin and Seghezza (2007) found that regionalism does not impede MFN tariff reduction. Indeed, they showed that the MFN tariffs (Most Favored Nation) and PTAs (Preferential Trade Agreements) are complementary and do not substitute since margins of preferences tend to be low or zero for products where countries apply high MFN tariffs.

However, Crawford and Laird (2001) showed that the rapid growth of trade agreements is a threat to the multilateral trading system. The orientation towards regional integration strategy seems to be explained by the fact that free trade can take much longer delay in the multilateral trading system in the regional integration agreements. If the multilateral trading system is credible, countries no longer consider the strategy of regional 
integration. Market access, which is the main concern of countries is better guaranteed in regional integration agreements in the multilateral trade agreements.

The first risk that the strategy of regional integration can cause is the negative impact on the multilateral trading system. But until now, no research has proved the existence of a full scale trade and investment. The effects of various regional integration agreements on trade in third countries can be summarized in a high probability of trade diversion towards countries of this agreement. It is thanks to the early work of Viner (1950) we observed that a regional integration agreement may result in a diversion of trade for the goods listed. This diversion depends on the form of the agreement of regional integration and trade policies of member countries.

The second risk of a regional integration strategy can be summarized in a division of the commercial geography in regional blocs. The creation of dominant economic powers and protectionist may present a danger to the multilateral trading system. Indeed, the use of aggressive strategies by the major economic powers will have a negative impact on international trade relations: the use of a protectionist trade policy by one of the regional groups necessarily leads to retaliation and anti-reprisals therefore a trade war is likely to be triggered.

The signing of several regional integration agreements concerned third countries about the future of their trade. The diversion of trade and investment to a regional grouping, which is not consistent with fundamental principles of the WTO can leave multilateralism in crisis. Indeed, whether the measures adopted by supporters of a trade agreement is not extended to third countries and regional preferences are maintained, there is a risk that third countries do not enjoy the same access to the large market of this regional group. The regional integration agreements attach great importance to the commercial interests of all parts of the regional group. Third countries that do not grant reciprocity, can not take advantage of market access of a regional grouping.

The solution that countries have adopted to avoid the risk of trade diversion is to join a regional group (Chaponnière and Vérez 2009). Thus, we saw the signing of several preferential trade agreements. While many agreements are not limited to countries of the same region, we speak of a PTA that can be a free-trade area or a customs union with a common external tariff.

The desire to join a regional group is explained by the fact that multilateral trade agreements are not credible and effective. If the approach of multilateralism was successful, the country will no longer consider integrating into regional groups. We can conclude that the multilateral trading system is in crisis because many countries wanted to try the regional integration strategy. If countries have changed the tactics of the game by integrating into regional groups is that the multilateral trading system is not working as it should. The regional integration strategy therefore prevails on the strategy of multilateralism. Countries thought that the regional integration agreements have better results than those of multilateral trade agreements.

The failure of the multilateral trading system to provide many benefits encourages countries to use regional integration strategy to take at least one market access of a regional group. Most countries have understood that the multilateral trading system has not yielded good results, especially with regard to market access: tariff will be more easily removed as part of a regional group in the framework of a multilateral trading system. Thus, the failure of the strategy of multilateralism has led to the success of the regional integration strategy.

Thus, faced with discrimination exercised by the commercial strategy of regional integration, the countries are still trying to fit into a regional group or through a membership, either by signing a preferential agreement such the fourth ACP-EEC Convention This tactic allows them to enter the market of a regional group while maintaining good relations with the member countries to avoid protectionist practices.

\section{The Forms of Regional Integration Agreements}

The regional integration can be either natural or strategic. Indeed, according to Jacquemin and Sapir (1991), "The natural integration" involves trading partners 'natural' which are geographically close, they pursue a liberal trade policy towards third countries. With respect to the strategic integration and according to the same authors (Jacquemin and Sapir). It means that members of a regional group pursue a common commercial policy at the expense of third countries.

The regional integration agreements are customs unions, such as the European Economic Community, to free trade zones which are based on reciprocal agreements such as EFTA and ELENA, by passing through non-reciprocal preferential agreements as the fourth ACP-EEC Convention of Lomé. These non-reciprocal preferential aims to facilitate the expansion of trade in some developing countries with no demand for reciprocity on the part of developed countries. The most of regional agreements involve free trade zones, whereas the agreements number of the creation of the customs unions is limited to a few examples such as the European Union, CARICOM and MERCOSUR. 


\section{The Characteristics of Regional Integration Agreements}

Since the inception of GATT creation until 1994, 108 RTAs have been notified to the GATT which 98 agreements have been notified under Article XXIV and the rest has been notified under the Enabling Clause (For more details, see page 98-117 Study of the WTO. "The regionalism and the world trading system", Geneva, April 1995). According to all of these agreements, 38 were notified between 1970 and 1979 and 37 between 1990 and 1994. It is the European Union that has signed the largest number of regional agreements: 41 of the 98 agreements which were notified to the GATT under the title of the Article XXIV took EEC as a partner. But, more generally, it is the Western Europe that adopted the most of the strategies of the regional agreements. In fact, the creation of the EEC (1957) and EFTA (1960) facilitated the signing of 76 regional agreements. In contrast, the regional agreements are almost absent among the countries in the developing world. This is explained in one part by the adoption of self-reliant development strategy, in the other part, by the existence of political unrest of these countries.

In addition, the majority of regional agreements are essentially the creation of free trade zones and more specifically those of a reciprocal type. The integration agreements that are creating the customs unions are very limited and mainly concern the EEC, CARICOM and MERCOSUR. But it should be noted that several regional agreements have either been replaced by other agreements, or ceased to be practiced. Therefore, the considerable number of regional agreements must not give us a false idea of the importance of regional integration strategy. Moreover, all the agreements began with the partial reduction of tariffs; the others went to the gradual removal of tariff barriers.

\section{The Polarization of International Economic Relations}

The regional integration strategy has resulted in the organization of major geographical areas in delimited and protected trading blocs. Several economists have seen in regional integration agreements the sign of the advent of three regional groupings are the United States, the European Union and the Asia-Pacific region. The risk that these three great powers can cause to themselves is likely a deterioration in the international economic relations. Therefore, we are witnessing a polarization of international economic relations around these three major economic powers that are trying to attract the maximum number of countries to win more markets.

The poles of the trade can only be economic superpowers that dominate all markets of goods and services. They are often made up of several countries to create a dynamic business inside the pole and try to attract the maximum number of other countries through a complete bond or a signature of a preferential agreement. Each pole tries to exert an influence on the international trading environment by encouraging countries to multiply trade relations with him. The pole strategy necessarily entails a regional concentration of trade in some areas that are economically powerful.

Regional integration facilitates the construction of hegemonic and powerful regions. The creation of the European Union is a good example to demonstrate the existence of a hegemonic power capable of exerting influence on other countries. The enlargement process of the European Union helped the formation of an economic power that prompted other countries to join the group, or at least to sign preferential agreements in order to receive certain benefits such as market access to the European Union.

The existence of hegemonic powers has much influence on the international trade relations that countries should set the trading bloc with whom they want to work. Each regional group aims to attract the maximum number of countries to form an economic or commercial power. The main purpose of an economic or commercial bloc is the domination of maximum market via a policy of enlargement or a signature of preferential agreements with third countries.

The regional integration agreements are therefore creating commercial powers. One of the objectives of regional agreements is to address the major economic powers that dominate the commercial world. The race for regional agreements or the enlargement strategy of a regional group shows that the followed objectives have a hegemonic order. The more trading block is stronger. The more the third countries and other regional groups are wary and take more precautions in the use of their trade policies because they know it is difficult to address such market power.

The strategy of regional enlargement is mainly adopted by the three most powerful trading blocs in order to dominate the global markets: the United States is seeking to create a free trade area by partnering with Canada and Mexico. The European Union is following its enlargement policy to other countries such as Eastern countries. As for Japan, it continues to adopt the opening policies, especially in Asia. 
For economic and political reasons, a regional group would largely dominant over the rest of the world. This domination allows it to control the game of international trade by attracting the maximum of countries that are playing solitary. It is in the sharing of markets that the confrontations are taking place between the most powerful regional groups. The developing countries, which are looking for the economic start, are more attracted by the regional groups who seek to be dominant. Thus, regional integration can be considered as a regional hegemonic strategy as it creates a competition of dominance between the major regional groups.

\section{The WTO and the Three Most Powerful Regional Blocs}

The WTO gives great importance to the three major economic powers in Europe, North America and the Far-East. This importance is based on the issue of competition and the type of relationship between these three trading blocs. "The only valid and viable perspective is that Europe, North America and the Far-East arrangements strengthen their regional arrangements of integration and cooperation in a multilateral stable - a common house - that provides clear and predictable rules and mechanisms to resolve the trade disputes coherently and objectively. If we want to strengthen and not to lose the multilateral system, we have no choice but to execute the Uruguay Round "(Declaration of the former General Director of GATT Peter Sutherland at a symposium on "Global competition: Europe against North America against Far-East," which was held in Cernobbio, Italy, September 4, 1993. News of the Uruguay Round." NUR 064. 6 September 1993. PP6).

The WTO insists on the fact that the regional groups should be open to the rest of the world. The regional integration strategy should be directed towards the construction of an effective multilateral trading system and without disloyal practices that violate the international competition. When commercial relations between these three blocks are dominated by a non-cooperative business environment, we begin to exchange blows by following commercial practices that are against the law of free trade. The protectionist policies, applied in the 30 s, showed us the disastrous consequences of international trade relations.

The WTO is trying to develop a cooperative environment between the three major economic powers by encouraging them to improve their commercial relations by trying to find an arrangement whenever there is a problem. "It would be morally and economically condemnable if the countries of North America, Western Europe and the Far-East, which have mostly benefited from the multilateral trading system, refuse to assume any responsibility to reinforce it now whereas it showed its universal value "(Declaration of the former General Director of GATT Peter Sutherland at a conference on" Global competition: Europe against North America against the Far-East ", which took place in Cernobbio, Italy, September 4, 1993." News of the Uruguay Round." NUR 0646 September 1993. Pp 4). During the Uruguay Round, there has been an increase in the number of trade issues between the regional blocs. The agricultural conflict between the EU and North America has impeded the conduct of international commercial negotiations and has nearly destroyed the Euro-American economic relations.

\section{Application to Regional Integration Model Principal-Agent}

The Principal-Agent model has been applied in several industries such as insurance service (Borche 1962), public procurement, industrial economy, the relationship between shareholder and manager, the relationship between the State and the private concessionaire ... We will use the Principal-Agent model to analyze the interaction between Preferential Trade Agreements and the Multilateral Trading System. In this paper, we develop a model of Principal-Agent type assuming that the WTO as the Principal and regional groups as Agents devices. The WTO should create mechanisms to encourage regional groups to respect the rules of international trade and in particular Article XXIV. The goal is to create mechanisms that should be optimal for the Principal and that solve the problem of information asymmetry (see Kadan, Reny and Swinkels 2001).

The Principal-Agent model is developed by the agency theory. Indeed, the general form of the agency relationship is defined as "a contract by which one or more persons (the mondant or the Principal) engage another person (the Agent or mondataire) to perform an action on their behalf, which involves the delegation to the Agent of a certain decision-making powers "(Jensen and Meckling 1976, p. 313). In general, "most agency problems involve a combination of adverse selection, moral hazard and risk-sharing" (Laffont 1987 p.18).

The existence of a conflict of interest between the Principal and the Agents has led many economists to look at this problem. Indeed, the presence of information asymmetry is the basis of the existence of conflicting interests between the Principal and the Agents. Problems of information asymmetry are present in two forms which depend on the nature of the information: the first concerns the anti-selection or adverse selection and the second form illustrates the problem of moral hazard or risk. 
The problem of adverse selection is based on the uncertainty about the agent type: the signing of the contract, the Principal does not know the hidden information by the Agent. So the Agent has private information about an exogenous variable. In contrast, the problem of moral hazard is a situation of hidden action after the contract signature: it is the behavior of the Agent that is unknown. Therefore, the Principal does not observe the action of the Agent which is an endogenous variable. Principal-Agent models can raise the case of adverse selection and the moral hazard: the Principal has no idea about the exogenous and endogenous variables.

The work of Grossman and Hart (1983), Rogerson (1985) and Jewit (1988) have developed Principal-Agent models in order to justify the approach of first order moral hazard. It should be noted that the agency relationship necessarily entails risk sharing. Theorists have argued that the type of contract that governs the relationship of agency may limit the opportunism of the Agent by encouraging them to exercise. Grossman and Hart (1983) point out that "in general, the action that is optimal for the agent depends on the extent of risk sharing between the Principal and the Agent." The objective is to determine the "optimal degree of risk sharing, in view of this dependence." These two authors have analyzed the problem of socialization of risk and struggle against opportunism (moral hazard stowaway).

Moral hazard model implicitly assumes that the Principal has the sole purpose of designing incentive contracts. For example, in models Holsmtrom (1979) and Grossman and Hart (1983), the Principal usually have interests to offer a contract that provides a variable remuneration for the Agent based on the realized profit.

The role of the WTO is to find a mechanism to reveal the exact information that holds the regional group. We call the principle of revelation in the game of the regional grouping, determination or detailed specification of a set of strategies for regional groups and an allocation rule for the WTO. As information is asymmetric and regional groups have the opportunity to influence the outcome in their favor, revealing a mechanism must be put in place by the WTO to eliminate any obstacle that hinders multilateralism. That is to say that the WTO should create a revealing mechanism that encourages regional groups to prevent damaging the trade of third countries.

Looking for a way to encourage regional groups to reveal their private information is the first concern that the WTO should do when it wants to eliminate all risks affecting the final result. Indeed, revealing mechanisms should be created to cope with the exploitation of hidden information. Thus, each revealing mechanism tends to encourage regional groups to be more honest by deploying more efforts in proclaiming their true characteristics.

\section{Modeling the Regional Agreements as a Principal-Agent Model}

The regional integration agreements can be modeled as a principal-agent model. The WTO can play the role of Principal since it is this organization that protects the commercial interests of all the Contracting Parties. In turn, the regional groups will form the peripheral agents that have a private information about the decisions and principles taken about trade with third countries. The WTO is going to defend the interests of third countries by trying to obtain the hidden information held by the regional groups. It must find a capable mechanism to encourage the regional groups to respect the rules of free trade and in particular Article XXIV.

\subsection{A Model of Hazard Moral Type}

The existence of asymmetric information can make regional integration agreements dangerous for the multilateral trading system. In fact, the members of a regional group can damage the trade of third countries by adopting rules that promote only the intra-group trade. Each regional group has an interest to avoid disclose an accurate information about the decisions and the actions that will be taken within the group.

This asymmetry of information is made of selfishness of regional groups: the objectives of the WTO and regional groups may not concord. The WTO is supposed to defend the commercial interests of all contracting parties, while the regional groups defend their own interests. The existence of a divergence of interests between the WTO, which seeks to find the general interest and the regional groups that seeks to find particular interest, obliges WTO to create incentives mechanisms. These mechanisms should make the game of trade between the regional groups and the third countries more transparent and cooperative.

Each regional group is the only one who knows the secrets of his actions. It can easily announce that it does not violate the rules of international trade and it does not affect the trade of third countries. But in reality there is often a preference to intra-group. The members of a regional group star with exporting and importing their products with the group before moving to the trade of third countries. These members can take advantage of certain discriminatory rules that the WTO does not know.

The asymmetric information and strategic behavior of the regional groups will have a negative impact on the multilateral trading system. The private information held by the groups of pressure gives them an advantage, especially in trade. Each member tries to be careful using unobservable methods that guarantee a good protection 
of the interests of all members of the regional group. Most of the regional groups give only the minimum information about the trade policy and the actions they will take.

Therefore, the presence of asymmetric information between the WTO and the regional groups may increase the unfair practices and disrupt the trade relations between the regional groups and third countries. The WTO should increase the efforts to control the policies and the actions of the regional groups to collect the maximum information.

Thus the moral hazard is present for all regional groups as soon as the WTO can not perfectly control the future actions of the regional groups. When the WTO agreements are given for the creation of a regional group, he does not know if the members do not divert trade to this group. There is always a risk that the members of a regional group do not comply with Article XXIV.

The WTO can not observe a variable correlated with the action of the regional group: the trade with the third countries. Then, we say that we are in second rank situation. So we will talk about the efforts to designate the trade made by the countries that are not directly observable. The role of the WTO is to encourage the regional groups not to divert trade to the members of these groups. The WTO must offer for the regional group a contract that consists in canceling the agreement of the regional integration if there is a violation of Article XXIV. So the informational asymmetry appears so after the signing of the contract: the action of the regional group is not directly observable.

\subsection{The Model Assumption}

The most important assumption of this model is to recognize that the WTO has the power to control the actions and commercial policies of the regional groups. It may also adopt a system of penalties against any regional group that does not comply with the Article XXIV. This system of penalties can even lead to the cancellation of the agreements of regional integration if it presents a danger to the game of international trade.

A regional group should choose an action $(\delta)$ from a set of possible actions $(\Delta): \delta \in \Delta$.

The implementation of the contract involves a set of states of the world $e$ with $e \in \mathrm{E}$.

The regional group has a trade policy that allows you to export a product $y=y(\delta, e)$ that allows to generate a profit $\pi(\delta, e)$.

The WTO represents the interests of all the Contracting Parties, in particular the interest of third countries, if there is regional integration agreement. We assume that the overall profit is shared between the WTO, which represents the benefit of third countries and the regional groups.

$\mathbf{r}(\mathbf{y})$ : a part of profit taken by the regional group.

$\pi-r(y)$ : a part of profit taken by the WTO (part of the benefit of third countries).

The trade of the member countries of a regional group is a signal that provides information about the action chosen by the regional group.

The preferences of the WTO and the regional group are described as the utility function of Von Neumann-Morgenstern.

$$
U^{G}=u^{G}(\pi-r(y)): \text { Utility function of the WTO }
$$

With: $\left.\quad u^{G^{\prime}}\right\rangle_{0} \quad$ and $\quad u^{G /} \leq 0$

$$
U^{I}=u^{I}(r(y))-C(\delta) \text { : Utility function of the regional group. }
$$

$$
\text { With: } \left.\left.\left.\quad u^{I^{\prime}}\right\rangle_{0} \quad, \quad u^{I^{\prime \prime}} \leq 0 \quad \text { and } \quad C^{\prime}\right\rangle_{0}, \quad C^{\prime \prime}\right\rangle_{0}
$$

Choosing an action $(\delta)$ from the part of the regional group leads to a law defined on the domain of profit. Suppose that $(G(\pi, \delta))$ the function of the distribution of the random $(\tilde{\pi})$ (probability that the benefit is greater than a given level) and $(g(\pi, \delta))$ its density of probability. The Initial richness is normalized to 0 .

$\mathbf{C}(\boldsymbol{\delta})$ : a function of the commercial policy that depends on the level of effort of the regional group (a level of effort that complies with Article XXIV). That is what we will name the disutility. 
The WTO maximizes the expected utility of the profit in the third countries under the incentive constraints and participation.

\subsection{The Incentive Constraint}

To the satisfaction of the incentive constraint, it is necessary that the regional group provides a level of effort which seems as advantageous as possible in the context of the WTO. The incentive constraint touches upon the effort to comply the Article XXIV. This constraint can be written as follows:

$$
\text { (IC) } \int\left(u^{I}(r(y))-C(\delta)\right) g(\pi, \delta) d y \geq \int\left(u^{I}(r(y)-C(\hat{\delta}))\right) g(\pi, \delta) d y
$$

\subsection{The Constraint of Participation}

The constraint of participation consists in the advantage of the regional group participation in the contract. This means that the regional group would agree to participate in the contract unless it gives a value superior or equal to $\left(\underline{\mathbf{U}}^{\mathbf{I}}\right)$. ( $\left.\underline{\mathbf{U}}^{\mathbf{I}}\right)$ is the utility that the regional group can get if it has no relationship with the WTO. This is what we call the next-best opportunity). The participation constraint is written as follows:

\section{(IR)}

$$
\int \mathbf{u}^{\mathrm{I}}(\mathbf{r}(\mathbf{y}))-\mathbf{C}(\boldsymbol{\delta}) \mathbf{g}(\mathbf{\Pi}, \delta) \mathbf{d y} \geq \underline{\mathbf{U}}^{\mathrm{I}}
$$

\subsection{The Resolution of the WTO Agenda}

The WTO must choose the contract $(\mathbf{r}(\mathbf{y}))$ that maximizes its expected utility, taking into account the impact of this contract on the decisions of the regional group:

$$
\operatorname{Max} \int u^{G}(\pi-r(y)) g(\pi, \delta) d y
$$

Under the constraints of the incentive and the participation:

$$
\begin{gathered}
\text { (IC): } \int\left(\mathrm{u}^{\mathrm{I}}(\mathrm{r}(\mathrm{y}))-\mathrm{C}(\delta)\right) \mathrm{g}(\pi, \delta) \mathrm{dy} \geq \int\left(\mathrm{u}^{\mathrm{I}}(\mathrm{r}(\mathrm{y})-\mathrm{C}(\hat{\delta}))\right) \mathrm{g}(\pi, \delta) \mathrm{dy} \\
\text { (IR): } \int u^{I}(r(y))-C(\delta) g(\pi, \delta) d y \geq \underline{U}^{I}
\end{gathered}
$$

With $\mathbf{G}_{\boldsymbol{n}}$ at least, three times continuously differentiable on its domain of definition of density $(\mathbf{g}(\boldsymbol{\pi}, \boldsymbol{\delta}))$. In the level $(\widehat{\boldsymbol{\delta}})$ of an insignificant effort different from $(\boldsymbol{\delta})$ : the most advantageous effort from the standpoint of the WTO.

The resolution of the WTO agenda is difficult to solve because of the existence of inequality in the incentive constraint. For this reason, we assume that the regional group put up only two possible actions $(\underline{\boldsymbol{\delta}})$ and $(\boldsymbol{\delta})$ with the probability of occurrence $(\underline{g})$ and $(\mathrm{g})$.

$(\overline{\mathrm{g}})$ stochastically dominates the first order $(\mathbf{g}: \overline{\boldsymbol{\delta}}\rangle \underline{\boldsymbol{\delta}})$. The disutility function (the function of trade policy depends on the level of effort) of regional group is the largest one: $(\overline{\mathbf{C}}>\mathbf{C})$.

We will assume that the WTO is neutrally in risk and that the regional group presents an aversion for the risk. Maximizing the expected utility of the WTO with respect to $\mathbf{r}$ gives the following optimality condition:

$$
\frac{1}{u^{\prime}}=\beta-\alpha\left(1-\frac{g(y)}{\bar{g}(y)}\right)
$$

Where $\boldsymbol{\beta}$ and $\boldsymbol{\alpha}$ are appropriate multipliers.

$\boldsymbol{\beta}$ : Multiplier associated with the participation constraint.

$\boldsymbol{\alpha}:$ Multiplier associated with the incentive constraint.

In case of $\boldsymbol{\alpha}=\mathbf{0}$ (incentive dimension), we find the condition of sharing the optimal of Borch risk where $\mathbf{r}(\mathbf{y})$ is constant. When $\boldsymbol{\alpha}$ is positive, $\mathbf{r}(\mathbf{y})$ must vary with $\mathbf{y}$. This reflects an arbitration between risk sharing, on the one hand, and the incitement to the effort, on the other hand. If the arbitration is not taken into account, the country would provide the minimum effort compatible with the maintenance of the contract. 
r (y) varies with the magnitude $\frac{\mathbf{g}}{\overline{\mathbf{g}}}$ : ratio of two densities of probability in the general case, that is to say, likelihood ratio. According to Laffont, the ratio measures the informative power of $\mathbf{y}$ designed as a signal.

Suppose that the action of the regional group is an unidimensional continuous variable of effort. In this case, the general writing of the incentive constraint can not be maintained. The only way of proceeding is to adopt an approach for the first order: we replace with the condition arg max indicating that, at the optimum, the expected utility of the regional group is stationary in its effort.

The condition of stationarity:

$$
\int \mathbf{u}^{\mathrm{I}}(\mathbf{r}(\mathbf{y})) \mathbf{g}(\mathbf{y}, \boldsymbol{\delta}) \mathbf{d y}-\mathbf{C}(\boldsymbol{\delta})=\mathbf{0}
$$

At the optimum, the expected marginal utility of effort must be equal to the marginal disutility. It is contained of a necessary first order condition but not sufficient. It does not always correspond to a correct approach: it offers a contract which sometimes does not verify the global incentive constraints of the original problem. Thus, we are led to study the conditions under which the first order approach is valid (Grossman and Hart 1983, Jewitt 1988, Rogerson 1985).

In order to obtain these conditions, by considering firstly a simple extension of the dichotomous case, we assume that the regional group controls a family of probability laws as the following :

$$
\mathbf{g}(\mathbf{y}, \boldsymbol{\delta})=\boldsymbol{\delta} \overline{\mathbf{g}}(\mathbf{y}, \boldsymbol{\delta})+(\mathbf{1}-\boldsymbol{\delta}) \underline{\mathbf{g}}(\mathbf{y}, \boldsymbol{\delta})
$$

This means that the regional group chooses his effort as a convex linear combination of two fixed probability laws $(\underline{\mathbf{g}}, \overline{\mathbf{g}})$. This relationship reflects a condition of linearity of the distribution function of the product of effort (spanning condition: condition of collection). If this condition is valid, the first order approach is valid, as well. But in the general case, this recovery condition is not necessary. We can take the linear approximation of the family law to the vicinity of the optimal effort $\left(\boldsymbol{\delta}^{*}\right)$ that the WTO wishes to embody. With the approach of the first order, we treat the problem as if the regional group chose its effort from a hypothetical form of laws.

$$
\mathbf{g}^{\prime}(\mathbf{y}, \delta)=\mathrm{g}\left(\mathbf{y}, \boldsymbol{\delta}^{*}\right)+\chi \mathbf{g}_{\delta}\left(\mathbf{y}, \delta^{*}\right)
$$

$\chi$ is very small, it is used when a cost function is :

$$
\bar{C}(\delta)=C\left(\delta^{*}\right)+\chi C^{\prime}\left(\delta^{*}\right)
$$

$\left(\mathbf{g}^{\prime}\right)$ is linear as in the case when the recovery condition is fulfilled. A problem remains:the WTO may want a law other than $\left(\mathbf{g}^{\prime}\right)$ in the family. If this is the case, it means that the WTO wants a sudden change in the appeared effort. The linear approximation is not sufficient.

The Lagrangian of the optimization problem is: (11)

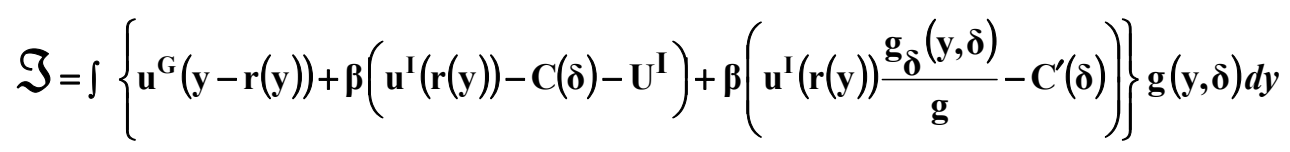

$\operatorname{Max} \mathfrak{I}$ (Static optimization) compared to $\mathbf{r}($.$) and \boldsymbol{\delta}$.

$$
\frac{\mathbf{u}^{\mathbf{G}^{\prime}}(\mathbf{y})-\mathbf{r}^{*}(\mathbf{y})}{\mathbf{u}^{\mathbf{I}^{\prime}}(\mathbf{r}(\mathbf{y}))}=\boldsymbol{\beta}+\boldsymbol{\alpha} \frac{\mathbf{g}_{\boldsymbol{\delta}^{*}}(\mathbf{y}, \boldsymbol{\delta})}{\mathbf{g}(\mathbf{y}, \boldsymbol{\delta})} \quad \text { first optimization condition }
$$

By using (7) (link optimization), we obtain the condition of the optimization effort.

$$
\int u^{G}(y-r(y)) g_{\delta^{*}}(y, \delta) d y+\alpha \int\left[u^{I}(r(y)) g_{\delta}(y, \delta)\right] d y=C^{\prime \prime}\left(\delta^{*}\right)
$$


(12): ratio likelihood written as a continuous form. If the condition of Milgrom and Shannon (1994: Monotonicity theorem) is satisfied, this ratio is increasing. This means that the Article XXIV thinks in the same time when its effort level thinks. The equation (12) indicates how the need to encourage the regional group led the WTO to deviate from a pure risk-sharing problem.

- If $\boldsymbol{\beta}=\mathbf{0}$, this means that the incentive dimension is absent, there is an optimal solution similar to that of Borch (1962), that is to say a solution of Pareto optimal risk sharing. This is called a solution of the first rank.

- If $\boldsymbol{\beta}$ is positive, this solution diverges from the first rank $\frac{\mathbf{g}^{\prime}(\boldsymbol{\delta})}{\mathbf{g}(\boldsymbol{\delta})}=\frac{\partial \log (\mathbf{g})}{\partial \boldsymbol{\delta}}$.

Comparing with the solution of the first rank, the deviation greater than the likelihood $\log (\mathbf{g})$. The difference is even more important than the informational content of the signal collected by WTO. The WTO itself is important when $\boldsymbol{\beta}$ is positive.

The WTO wants effort of the regional group to be greater than in the case of the first rank of risk sharing. To encourage him to provide greater effort, the WTO must periodically control the trade policies of the regional group and should verify if there is a violation in the Article XXIV. Since the WTO has all the power, the regional group does not have to cheat if it wants its integration agreement not to be canceled.

\subsection{The Conclusion of the Model}

In this model, we have seen that there is a problem of ignorance of the actions and decisions of the regional groups. The hidden information held by regional groups can lead to unfair practices that may impede the third countries trade, and thus cause a destructive trade war.

The WTO should be able to observe perfectly all the actions of the regional groups that affect the usefulness of the third countries. In other words, the WTO must ensure that the commercial interests of third countries are not damaged. This means that the WTO should make more extensive control efforts on the trade policies of the regional groups.

If the WTO can observe the action of the regional groups, it is in the case of the first rank. In the case of trade diversion, the WTO must cancel the regional integration agreement. In contrast, in the case of compliance with the Article XXIV, the WTO should encourage the regional groups to continue in this direction.

The trade policies of regional groupings are more mostly controlled by the WTO, especially those who may present a threat to the multilateralism. It is the existence of certain rules that benefit the members of a regional group that worries the WTO and leaves him more attentive towards the unfair practices employed by these regional groupings. What is essential for The WTO is not to allow the regional groups adopt trade policies that do not comply with the rules and principles of free trade.

The Negotiations of the Uruguay Round enabled surveillance increased by the GATT trade policies of all the Contracting Parties. Indeed, a periodic review mechanism is set up to control all the unfair practices that go against the rules of the WTO. The Trade Policy Review of the contracting parties, which is one of the main concerns of the WTO, is carried out according the importance of countries or the regional groups.

The establishment of review mechanism of trade policies of contracting parties intended to ensure greater efficiency in the evaluation of the effect of the Contracting Parties business strategies to the multilateral trading system. This mechanism can help us build a more transparent business environment, which, as we know, is one of the fundamental principles of the WTO. The trade policy review affects especially the main business entities and in the place, the most powerful regional group. For example, the importance of the European Union exchange requires the review mechanism to be replaced every two years.

By controlling, every two years, the trade policies of major economic powers clearly explain that these trade blocs pose a threat to the multilateral trading system. The major trading powers are primarily responsible for the success or failure of the multilateralism.

Over 80 regional agreements reviewed by the WTO, only six were considered consistent with WTO principles (the European Economic Union is not included). This explains that the most regional groups use rules that are incompatible with the multilateralism strategy. The adoption of trade policies, oriented only to the regional preference, is the most abundant of all forms of the regional integration strategy. This preference concerned the WTO and forces him to reinforce the control of the regional integration agreements whatever their forms are.

The 69 working groups, who were appointed to examine the 98 agreements were notified in January 1995 under the Article XXIV, concluded that there are two regional integration agreements that are consistent with Article 
XXIV. These two agreements are those that were signed between the Community and the Caribbean Common Market (CARICOM), in the one hand, and those of the Customs Union that were signed between the States of the former Czech and Slovak Federal Republic, in the other hand. For other agreements, the working groups were unable to reach a consensus as most member countries of an integration agreement announced that this latter is consistent with Article XXIV of the WTO while the third countries insist that such agreements are not compatible with this article.

However, among the examples of non-compliance integration agreements with Article XXIV of the WTO, we may mention the tariff treatment of EU imports of citrus industry products from certain countries of the Mediterranean region. This tariff treatment, was concluded in 1982, was considered by the U.S. incompatible with the principle of the most favored nation (MFN). This judgment has been confirmed by a special group that was appointed to resolve this case. Moreover, two other complaints filed by third countries on non-compliance integration agreements with WTO rules, were against the European Community.

\section{Conclusion}

The interplay between the regional groups remains uncooperative because everyone is trying to dominate the trade by attracting the maximum number of countries. This non-cooperative environment requires the presence of the WTO that must both set the rules of the international trade and control the trade policies of countries especially those regional groups that dominate the commercial exchanges.

We have shown that the regional agreements can be modeled as a Principal-Agent model. The resolution of this model is based on a very important assumption that is to give all the power to the WTO to cancel the regional agreements that constitute a new form of protectionism and pose a threat to the multilateralism. It has become necessary that the WTO should establish a legal authority that obliges the regional groups to respect the rules of free trade and in particular Article XXIV.

The regional groupings aim to strengthen the political economic and social relations between different countries in a group regardless of its level of development. The regional integration aims to accelerate the economic growth in member countries. The financial aid should be give to the least developed countries so that they can face the most serious economic problems. These aids also aim to promote convergence among the member countries of the regional group.

Most countries, especially the least developed, are seeking to ally with major trading blocs. These countries consider being a member of a powerful regional group as it enjoys lot of benefits such as free movement of goods, services and factors of production. In addition, the solidarity principle, adopted by most regional groups and served to assist countries with the greatest difficulties, has prompted several countries to move towards the regional integration strategy.

According to the WTO, the regional integration strategy must be consistent (complementary or compatible) with a globalization of trade and investment. The WTO considers that the regional and multilateral approaches should be complementary. The regional integration strategy should lead to a significant multilateral trade liberalization. With a liberal trade policy, this strategy should have a positive impact on the global trade.

But, the current economic and financial crises are not in favor of the strategy of multilateralism. The existence of several factors (high unemployment, sluggish economic growth, rising food prices, ...) has encouraged countries to use protectionist trade practices especially in harsh forms (such as measures so-called "gray zone "and the agreements of voluntary restraint) or soft (such as sanitary and phytosanitary barriers and technical barriers to trade)

The WTO must find a mechanism that requires countries to comply with Article XXIV, or more precisely a mechanism which removes all unfair practices employed by regional groups. Without this mechanism, there will always exist trade problems between countries. Consequently, the game environment of international trade is often tense. The Revealing mechanism created by the WTO must steer countries towards legal free trade and without free protectionist practices.

\section{References}

Baldwin, R. (2010). Sequencing Regionalism: Theory, European Practice, and Lessons for Asia. CEPR Discussion Papers 7852, C.E.P.R. Discussion Papers.

Baldwin, R. (2009). Integration of the North American Economy and New-Paradigm Globalization. CEPR Discussion Papers 7523, C.E.P.R. Discussion Papers.

Baldwin, R., \& Jaimovich, D. (2009). Are Free Trade Agreements Contagious? CCES Discussion Paper Series 12, Center for Research on Contemporary Economic Systems, Graduate School of Economics, Hitotsubashi 
University.

Baldwin, R., \& Seghezza, E. (2007). Are Trade Blocs Building or Stumbling Blocks? New Evidence, CEPR Discussion Papers 6599, C.E.P.R. Discussion Papers.

Baldwin, R., \& Venables, A. (1995). Regional Economic Integration. In Dans Grossman G., Rogoff K. (Eds), Handbook of international economics, III (pp. 1597-1644). Amsterdam, North-Holland.

Borch, K. (1962). Equilibrium in a Reinsurance Market. Econometrica, 30, 424-444. http://dx.doi.org/10.2307/1909887

Chaponnière, J. R., \& Vérez, J. C. (2009). L'évolution des échanges commerciaux entre l'Union européenne et la Turquie depuis l'union douanière de 1995. Economie Appliquée, 62(4), 99-130.

Clergerie, J. L., Gruber, A., \& Ramband, P. et. (2010). L'Union Européenne. Dalloz, 928.

Commission Européenne. (2008). Une stratégie pour l'avenir de l'union douanière, Communication de la Commission au Conseil, au Parlement européen et Comité économique et social européen. COM/2008/0169 final.

Crawford, J. A., \& Laird, S. (2001). Regional Trade Agreements and the WTO. The North American Journal of Economics and Finance, 12(2).

Deblock, C., \& Dorval, B. (1993). Une intégration régionale stratégique: le cas nord-américain. Etudes Internationales, 2(3), 595-629. http://dx.doi.org/10.7202/703211ar

Draper, P. (2010). Rethinking the (European) Foundations of African Economic Integration: A Political Economy Essay, Document de travail du centre pour le développement de l'OCDE no 293. Voir également l'article du même auteur dans Éclairage, 10(4).

Figuière, C., \& Guilhot, L. (2009). L'intégration économique régionale : parangon de la complémentarité entre l'économie internationale et l'EPI, Colloque international "Économie politique internationale et nouvelles régulations de la mondialisation." Centre de Recherche sur l'Intégration Économique et Financière, Université de Poitiers, Poitiers, 14-15 mai 2009, 17 p.

Figuière, C., \& Guilhot, L. (2007). Vers une typologie des "processus" régionaux. Le cas de l'Asie Orientale. Revue Tiers-Monde, 192, 895-917. http://dx.doi.org/10.3917/rtm.192.0895

GATT. (1993). La concurrence mondiale : Europe contre Amérique du Nord contre Extrême-Orient, Colloque qui a eu lieu à Cernobbio, ITALIE, le 4 septembre 1993. Nouvelles de l'Uruguay Round".NUR 064. 6 septembre 1993. p. 6.

Goyette, G. (2006). Protectionnisme et réciprocité commerciale : répertoire des obstacles au commerce maintenus par les Etats-Unis, Cahier de Recherche. Centre Etudes Internationales et mondialisation. Institut d'études internationales de Montréal. Université du Québec à Montréal.

Grossman, S. J., \& Hart, O. D. (1983). An Analysis of the Principal-Agent Problem. Econometrica, 51(1), 7-45. http://dx.doi.org/10.2307/1912246

Holmstrom, B. (1979). Moral Hazard and Observability. Bell Journal of Economics, 10, 74-91. http://dx.doi.org/10.2307/3003320

Hauser, H., \& Zimmermann, T. A. (2001). Régionalisme ou multilatéralisme, La vie économique; Revue de politique économique.

Jensen, M. C., \& Meckling W. H. (1976). Theory of the Firm: Managerial Behavior, Agency Costs and Ownership Structure. Journal of Financial Economics, 3(4), 305-360.

Jewitt, I. (1988). Justifying the First-Order Approach to Principal-Agent Problems. Econometrica, 56(5), 1177-1190. http://dx.doi.org/10.2307/1911363

Kadan, O., Reny, P. J., \& Swinkels, J. M. (2001). Existence of Optimal Mechanisms in Principal-Agent Problems, 1 Janvier 2011 IMF Working Paper n ${ }^{\circ} 2011-002$.

Kearney, P. (2008). 40 ans d'Union douanière, Revue du Marché commun et de l'Union européenne, n. 522, octobre-novembre, pp. 581-586.

Khavand, F. (2001). Commerce international: le Régionalisme menace t-il l'universalisme?, Institut International d'Etudes Stratégiques - Paris, France.

Khavand, F. (1995). Le nouvel ordre commercial mondial, Nathan. Paris. 192p. (Collection Circa; 34). 
Laffont, J. J. (1987). Le risque moral dans la relation de mondat. Revue Economique, 38(1), Janvier.

Mashayekhi, M., \& Taisuke, I. (2005). Multilatéralisme et régionalisme: la nouvelle interface, CNUCED; Nations Unies. New York et Genève.

McMillan, J. (2010). La politique réglementaire communautaire pour la libre circulation des marchandises et l'approfondissement/ achèvement du marché intérieur, Revue du droit de l'Union européenne, n. 2, pp. 229-285.

Milgrom, P., \& Shannon, C. (1994). Montone Comparative Statics. Econometrica, 64, 157-181. http://dx.doi.org/10.2307/2951479

OCDE. (2001a). Politiques de la concurrence et des échanges: options pour une plus grande cohérence, OCDE. Paris.

OCDE. (2001b). Intégration régionale : effets commerciaux et autres effets économiques observés, TD/TC/WP 2001, 19/ FINAL Paris.

OCDE. (2003). Le régionalisme et le système commercial multilatéral, OCDE. Paris.

OMC. (1997). Dossier spécial : le commerce et la politique de la concurrence, Rapport Annuel de l'OMC 1997. Volume 1. Organisation Mondiale du Commerce. Genève.

OMC. (1995). Le régionalisme et le système commercial mondial, Rapport Annuel de l'OMC 1997. Genève, Avril 1995.

Paugam, J. M. (2007). Commerce mondial : avec ou sans l'OMC? Problèmes économiques, 2(915), 17 janvier.

Piergiuseppe, F., \& Valensisi, G. (2011). Intégration commerciale régionale et opportunités de développement: l'expérience africaine, International Centre for Trade and Sustainable Development. Eclairage, 10(6) .

Rogerson, W. (1985). The First-Order Approach to Principal-Agent Problems. Econometrica, 53, 1357-1368. http://dx.doi.org/10.2307/1913212

Shadikhodjaev, S. (2009). Trade Integration in the CIS Region: a Thorny Path Towards a Customs Union. Journal of International Economic Law, 12(3), 555-578. http://dx.doi.org/10.1093/jiel/jgp023

Siroën, J. M. (2000a). Régionalisme et multilatéralisme, Les cahiers français 11/2000 n 299. pp. 34-40.

Siroën, J. M. (2000b). La régionalisation de l'économie mondiale, La découverte. Paris. 121 p. (Collection Repères; 288).

Trotignon, J. (2009). L'intégration régionale favorise-t-elle la multilatéralisation des échanges? Revue française d'économie, 23(3), 213-246.

Tshiyembe, M. (2012). Régionalisme et problèmes d'intégration économique: ALENA, MERCOSUR, Union Européenne, Union Africaine, L'Harmattan. Paris.

Venables, A. J. (2000). Winners and Losers From Regional Integration Agreements. Discussion Paper, Centre for Economic Policy Research. London.

Viner, J. (1950). The Customs Union Issue. New York, Carnegie Endowment for International Peace. 